Полагаем, что при проведении процедуры медиации, кроме необходимости базовых юридических знаний, требуется профессиональные знания психологии. Так, Курмаева Н.А. и Кулагина М.Н. считают, что для процедуры медиации необходимо владеть достаточным уровнем знаний в области психологии, педагогики и конфликтологии [7, с. 15]. Кроме того, Пантелеева И.А. предлагает привлекать психолога в целях повышения результативности процедуры медиации и обеспечения максимальной психологической комфортности для ее участников [8, с. 456].

На наш взгляд, психологическая сторона разрешения конфликта и возможность участия квалифицированного психолога либо конфликтолога вполне оправдана, можно провести своеобразную аналогию с присутствием адвоката-защитника в судебном процессе. В то же время дополнение законодательных условий для проведения процедуры медиации может повлечь ее усложненность с точки зрения организации. Следовательно, в рамках Программы подготовки должны разрабатываться строгие требования по отношению к профессиональным медиаторам.

В заключение отметим, что альтернативная процедура урегулирования споров с участием в качестве посредника независимого лица - медиатора делает эту примирительную процедуру перспективным институтом разрешения правовых споров и иных конфликтов.

\title{
***
}

1. Об альтернативной процедуре урегулирования споров с участием посредника (процедуре медиации): Федеральный закон от 27 июля 2010 № 193-Ф3 (ред. от 26.07.2019).- Режим доступа: // Справочная правовая система КонсультантПлюс (дата обращения: 10.11.20).

2. оваленко А.Г., Яковлева А.П. Некоторые проблемы реализации судебной реформы в России // Правовая политика и правовая жизнь. 2005. - № 3. С. 93-100.

3. Гражданский процессуальный кодекс Российской Федерации: Федеральный закон от 14 ноября 2002 № 138-Ф3 (ред. от 31.07.2020).- Режим доступа: // Справочная правовая система КонсультантПлюс (дата обращения: 10.11.20).

4. О статусе судей в Российской Федерации: Закон Российской Федерации от 2 июня 1992 № 3132-1 (ред. от 31.07.2020).- Режим доступа: // Справочная правовая система КонсультантПлюс (дата обращения: 10.11.20).

5. Судебный департамент при Верховном Суде Российской Федерации. Данные судебной статистики. URL:http://www.cdep.ru/index.php?id= 79\&item=5258 (дата обращения: 09.10.2020).

6. Негода Н.О., Танасиенко И.И. Медиация в банкротстве // Бюллетень науки и практики. 2019. Том 5. - № 1. С. 347-351.

7. Курмаева Н.А., Кулагина М.Н. Преимущества и недостатки семейной медиации в России // Вопросы экономики и права. 2019. - № 132. С. 15-18.

8. Пантеева И.А. Семейная медиация как альтернативная процедура разрешения споров // Вестник ННГУ. 2014. - № 1. С. 452-457.

\section{Сынков В.В.}

\section{Институт присяжных заседателей по Уставу Уголовного Судопроизводства для} Германской Империи 1877 года

Санкт-Петербургский юридический институт (филиал) Университета прокуратуры Российской Федерачии (Россия, Санкт-Петербург)

doi: $10.18411 / \mathrm{lj}-12-2020-290$

idsp: ljournal-12-2020-290

\section{Аннотация}

В статье рассматривается законодательное регулирование института присяжных заседателей в Уставе Уголовного Судопроизводства для Германской Империи 1877 года. Кроме того, проводится сравнительный анализ регулирования института присяжных в Уголовно-процессуальном кодексе Российской Федерации. Также обосновано значение института присяжных в правовом демократическом обществе. 
Ключевые слова: присяжные заседатели, Устав Уголовного Судопроизводства, УПК РФ, правовое государство, значение

Abstract

The article examines the legislative regulation of the institution of jurors in the Charter of Criminal Procedure for the German Empire of 1877. In addition, a comparative analysis of the regulation of the institution of juries in the Criminal Procedure Code of the Russian Federation is carried out. The importance of the institution of the jury in a democratic legal society is also substantiated.

Keywords: jurors, Charter of Criminal Procedure, Code of Criminal Procedure of the Russian Federation, rule of law, meaning

Суд с участием присяжных заседателей - одна из важных гарантий построения демократического правового государства. Внедрение данного института в уголовное судопроизводство России справедливо рассматривается учеными как реализация конституционного принципа участия граждан в отправлении правосудия.

Участие непрофессионального элемента в постановлении приговора рассматривалось как прогрессивное достижение юридической науки еще в 19 веке. Так, кандидат прав И. Соболев отметил, что главнейшим изменением в проекте Устава Уголовного Судопроизводства для Германской Империи от 1 Февраля 1877 года было принятие отдела, направленного на регулирование производства в суде с участием присяжных заседателей.

Отметим, что нормы Устава Уголовного судопроизводства для Германской Империи (далее по тексту - Устав) весьма прогрессивны в вопросах регулирования судопроизводства судом с участием присяжных заседателей. Обратимся к нормам упомянутого памятника права и проведем сравнительный анализ с нормами Уголовнопроцессуального кодекса Российской Федерации (далее по тексту - УПК РФ).

Производству в суде с участием присяжных заседателей был посвящен отдел седьмой Устава - «Главное следствие перед присяжными». Данный отдел включал в себя 42 параграфа, и структурно его можно было разделить на шесть частей:

1. Bопросы, связанные с формированием коллегии присяжных заседателей (\$277-\$287). Коллегия присяжных формировалась председательствующим путем «вынутия жребия» в открытом заседании. При этом список очередных присяжных вручался подсудимому в случае, если последний находился не на свободе, либо [список] был готов для обозрения в канцелярии суда для подсудимого, находящегося на свободе. Существовали условия, которые исключали право лица участвовать в качестве присяжного заседателя, а также условия, влекущие устранение от исполнения обязанностей присяжного. Был предусмотрен также количественный критерий коллегии присяжных заседателей. К производству по делу можно было приступить в случае, если наличествует не менее 24 присяжных заседателей. Современный УПК РФ схожим образом регулирует вопросы формирования коллегии присяжных в ст. 328. Кроме того, ст. 3 Федерального закона от 20.08.2004 года № 113-Ф3 «О присяжных заседателях федеральных судов общей юрисдикции в Российской Федерации» (далее 113-Ф3) предусмотрены условия, которые исключают возможность участия лица в качестве присяжного заседателя. А в ст. 7 113-Ф3 предусмотрены условия, которые влекут исключение из списков присяжных (не путать с условиями, указанными в ст. 3).

2. После урегулирования вопросов формирования коллегии присяжных заседателей последние приводились $к$ присяге, текст которой был прямо предусмотрен в 288 Устава. Конечно, такую присягу можно рассматривать как архаизм, поскольку ответственность присяжного подкреплялась, по сути, только клятвой «Богом Всемогущим и Всеведающим». Современный УПК РФ также предусматривает присягу присяжного, которая сформулирована более подробно и 
обстоятельно. Однако никакой ответственности за нарушение присяги ни в Уставе, ни в УПК РФ не предусмотрено. В связи с этим, подобную меру подкрепления ответственности присяжных не стоит рассматривать как эффективную. Относительно УПК РФ следует отметить, что нам видится весьма перспективным предложение В.Б. Кругляковой об установлении правовых санкций за нарушение присяжной нормы. Однако нельзя не отметить, что такой подход требует разработки критериев нарушения присяги.

3. Bопросы собственно производства по делу. С учетом нормы §276 производство по делу осуществляется в соответствии с общим порядком, предусмотренным шестым отделом Устава.

4. Bопросы, связанные с формированием вопросного листа для присяжных заседателей (\$290-\$301 Устава). Вопросы формулировались так, чтобы на них можно было ответить «да» или «нет». При этом существовало несколько типов вопросов. Вспомогательные вопросы были направлены на проверку квалификации деяния, которое отступало от квалификации, вменяемой подсудимому в определении об открытии главного производства. Кроме того, в вопросном листе могли формулироваться побочные вопросы, касающиеся обстоятельств, смягчающих или отягчающих наказание. Также побочный вопрос ставился, если подсудимый не достиг восемнадцати лет к моменту совершения деяния. Главным был вопрос о виновности подсудимого в совершении вменяемого ему деяния. Представляется также, что §292 Устава подразумевает и иные вопросы, не относящиеся ни к одной из вышеперечисленных категорий. Так, вопрос о доказанности самого существования деяния нельзя отнести ни к вспомогательным, ни к побочным. Назовем эту категорию обычными вопросами. Нам видится весьма правильным положение §300 Устава, который позволял председательствующему делать наставление присяжным относительно правовых точек зрения. УПК РФ схожим образом регулирует вопросы формирования вопросного листа для присяжных.

5. Bопросы, связанные с обсуждением присяжными вердикта в совещательной комнате (\$301-§307). Для обсуждения вопросов вопросного листа присяжные заседатели удаляются в совещательную комнату. Во время обсуждения обеспечивается полная изоляция присяжных от иных участников процесса. Кроме того и присяжным воспрещалось покидать совещательную комнату без позволения председательствующего. Руководит работой присяжных в совещательной комнате старшина присяжных, который избирается путем письменного голосования по большинству голосов. Решение принимается большинством голосов. При этом предъявлялись особые требования в случае решения не в пользу подсудимого.

6. Вопросы оглашения вердикта присяжных и последствия его оглашения (\$308-\$317). Вердикт оглашается в зале заседания старшиной присяжных. Старшина последовательно зачитывает вопросы вопросного листа и ответы, которые присяжные на них дали. В случае неправильности или неясности вердикта председательствующий предлагает присяжным удалиться в совещательную комнату для устранения недостатков. В случае вынесения оправдательного вердикта суд объявляет подсудимого невиновным. Стоит отметить, что Уставом было предусмотрено право суда признать, что присяжные ошиблись в главном вопросе о виновности подсудимого. В таком случае суд принимал решение о направлении дела на новое рассмотрение. Причем не один из присяжных, участвовавших в процессе, не может участвовать в новом процессе по делу. Дальнейшее несогласие суда с вердиктом присяжных недопустимо - «на основании нового вердикта приговор постановляется во всяком случае».

Отдельно необходимо остановиться на вопросе о том, какая модель суда с участием присяжных заседателей была реализована в Уставе. Как указывает Т.Ю. Маркова, существует две модели разделения полномочий между 
председательствующим и присяжными заседателями. Первая модель - факта и права присяжные заседатели решают только фактические вопросы, а председательствующий судья только юридические. Вторая модель предполагает, что присяжные решают вопрос о виновности, а председательствующий назначает наказание подсудимому на основании вердикта присяжных. Классическая модель (факта и права) полностью реализована только в Англии. Нам видится, что модель вины и наказания выглядит более рационалистично. Как указывает Г.Н. Борзенков, требование четкого отграничения вопросов факта от вопросов права практически не осуществимо. Анализ норм Устава позволяет прийти к выводу, что в нем была реализована модель вины и наказания. Присяжные отвечали на главный вопрос о виновности лица в совершении преступления, а профессиональный судья решал вопрос о наказании (с учетом смягчающих и отягчающих обстоятельств, существование которых также устанавливалось присяжными заседателями). В УПК РФ реализацию получила смешанная модель. Так, ч. 7 ст. 335 УПК РФ закрепляет, что в ходе судебного следствия в присутствии присяжных заседателей подлежат исследованию только те фактические обстоятельства уголовного дела, доказанность которых устанавливается присяжными заседателями в соответствии с их полномочиями, предусмотренными статьей 334 настоящего Кодекса. Однако, как и в Уставе в УПК РФ основным является вопрос о виновности лица в совершении преступления. На основании вердикта коллегии присяжных профессиональный судья либо вынесет оправдательный приговор (в случае оправдательного вердикта), либо решит вопрос о виде и мере наказания (в случае, если присяжные признают лицо виновным в совершении преступления).

В заключение хочется отметить следующее. Тема суда с участием присяжных заседателей уже достаточно «избита» - написано большое количество статей, учебных пособий, монографий. Существуют целые серии видеоматериалов о присяжных заседателях. Так, в 90-е - начало 00-х при поддержке ГПУ Администрации Президента РФ было снято большое количество обучающих фильмов по присяжным заседателям. Однако в обществе по-прежнему не утихают споры о том, нужен ли вообще институт присяжных в уголовном процессе. Заслуженный юрист РФ В. Зыков указывает на то, что существование суда присяжных нарушает нормы Конституции о правовом государстве - мол, присяжные не обязаны соблюдать закон. А как же норма об участии граждан в отправлении правосудия, закрепленная в ч. 5 ст. 32 Конституции РФ? Или господин В. Зыков о ней забыл?

Указывают на некомпетентность присяжных. Однако присяжные и не должны быть обременены юридическими знаниями. При принесении присяги они клянутся разрешать уголовное дело по своему внутреннему убеждения и совести. А проблема неправильного уяснения какого-либо вопроса - это проблемы профессиональных участников судебного процесса. Как отмечают А.В. Холопов и Г.Г. Непеин рассмотрение уголовных дел в суде с участием присяжных заседателей осложняется отсутствием у прокуроров практических навыков применения методов познания преступления. В суде с участием присяжных заседателей от прокуроров требуется повышенный уровень владения материалами уголовного дела, обеспечение наглядности и доступности процесса познания совершенного преступления. При ознакомлении с новостными статьями по поводу того, что присяжные вновь оправдали очередного «преступника», обнаруживается, что в уголовное дело всегда закрадывается какое-нибудь «но»: то доказательств, опровергающих версию стороны защиты недостаточно (стороне обвинения итак все ясно, зачем еще собирать доказательства и опровергать версию стороны защиты), то доказательства стороны обвинения недостаточно подтверждают вину подсудимого. На наш взгляд, институт присяжных, наоборот, способствует повышению качества расследования, заставляя сторону обвинения более тщательно подходить к вопросу сбора и фиксации доказательств. 
Институт присяжных крайне положительно оценивался и дореволюционными учеными. Так, Л.Е. Владимиров писал: «Кто изучал институт присяжных на западе, должен был выработать убеждение, что это - лучшая форма суда, какая только может быть указана в истории». На недопустимость отмены института суда присяжных указывал и А.Ф. Кони.

Таким образом, институт присяжных заседателей - прогрессивное достижение уголовно-процессуальной науки. Как показывает история, он регулировался весьма прогрессивно еще в 19 веке, о чем свидетельствуют нормы Устава Уголовного судопроизводства для Германской Империи от 1 февраля 1877 года. На наш взгляд, участие присяжных заседателей в отправлении правосудия служит серьезной правовой гарантией построения демократического, правового государства.

1. Батырбаев Б. Судья факта в уголовном судопроизводстве Кыргызской Республики // ALATOO ACADEMIC STUDIES. - 2017. - № 4. - C.140-148.

2. Владимиров Л.Е. Суд присяжных. Условия действия института присяжных и метод разработки доказательств / Л.Е. Владимиров. - Харьков : Университетская Типография, 1873. - 265 с.

3. Кони А.Ф. О суде присяжных и о суде с сословными представителями / А.Ф. Кони. - С.-Петербург : Типография Правительствующего Сената, 1895. - 31 с.

4. Круглякова В.Б. Проблемы реализации присяжной нормы // Вестник Поволжского института управления. - 2009. - № 4 (21). - С.107-110.

5. Маркова Т.Ю. Постановка вопросов, подлежащих разрешению присяжными заседателями / Т.Ю. Маркова. - М.: Юрлитинформ, 2010. - 168 с.

6. Медиафайлы [Электронный ресурс] // Суд присяжных : http://jurytrial.ru/library/media (дата обращения: 24.11.2020).

7. Непеин Г.Г., Холопов А.В. Институт суда с участием присяжных заседателей как реализация конституционных принципов в развитии гражданского общества в России // Криминалистъ. 2019. - № 3 (28). - С.26-31.

8. Суд присяжных: «за» и «против» [Электронный ресурс] // Аргументы и факты : сайт. - 2020. URL: https://aif.ru/archive/1680399 (дата обращения: 24.11.2020).

9. Суд присяжных ущемляют. Некомпетентен или неугоден прокурорам? [Электронный ресурс] // ПРАВORU : сайт. - 2020. - URL: https:/pravo.ru/review/view/32986/ (дата обращения: 24.11.2020).

10. Устав Уголовного судопроизводства для Германской Империи с Законом о введении его в действие 1 февраля 1877 года / пер. кандидата прав Ив. Соболева. - С.-Петербург : Типография и хромолитография А. Траншеля, Стремянная 12, 1878. - 135 с

\section{Тагиров Э.К. \\ Общее понятие договора возмездного оказания услуг}

Башкирский Государственный Университет

(Россия, Уфа)

doi: 10.18411/lj-12-2020-291

idsp: ljournal-12-2020-291

\section{Аннотация}

В данной статье раскрывается общее понятие договора возмездного оказания услуг, его виды, правовая база, условия о его предмете.

Ключевые слова: Договор возмездного оказания услуг, предмет договора, обязательные условия, виды договора возмездного оказания услуг, обязательные условия, случайные условия, дополнительные условия.

Определение договора возмездного оказания услуг ГК РФ содержится в п. 1 ст. 779 ГК РФ. Согласно этой норме, под этим договором мы должны понимать соглашение сторон, где одна сторона исполнитель, которая обязуется оказать указанные в нем услуги, а вторая сторона - заказчик, который должен принять и оплатить эти услуги. Из названия договора следует его возмездный характер, его консенсуальность и участие в нем двух сторон. 